\title{
The Meeting Between Marius and Mithridates And the Pontic Policy in CAPPADOCIA
}

\author{
MariUs VE MITHRIDATES'IN BULUSMASI VE KAPPADOKIA'DAKİ PONTOS \\ POLİTIKASI
}

\author{
LUIS BALLESTEROS-PASTOR*
}

\begin{abstract}
The meeting between Marius and Mithridates Eupator prevented a Pontic annexation of Cappdocia. The Roman leader warned the Pontic king and threatened him with war. Mithridates belonged to the Ariarathid house of Cappadocia because Laodice, the king's mother, was a member of this royal family. Accordingly, Eupator tried to intervene in Cappadocian affairs, as shown in the coincidence between his accession to the throne and the murder of Ariarathes VI ca.110 B.C. After the death of both Ariarathes VII and his brother Ariarathes VIII, Mithridates was the eldest male member in the Ariarathid line of succession, and an annexation of Cappadocia would have been well justified. The setting of the young Pontic prince Ariarathes IX on the throne was a temporary solution, but both Rome and a sector of the Cappadocian nobility did not agree, and Ariobarzanes I Philorhomaios was appointed king.
\end{abstract}

Keywords: Marius • Mithridates Eupator • Ariarathes • Cappadocia $\bullet$ Pontus $\bullet$ Sulla $\bullet$ Ariobarzanes.
Öz: Marius ile Mithridates Eupator arasındaki karşılaşma, Kappadokia'nın Roma tarafından ilhak edilmesini önledi. Romalı lider, Pontos kralını ikaz ederek onu savaşla tehdit etti. Kralın annesi Laodike, Ariarathes kraliyet ailesinin bir mensubu olduğu için Mithridates de Kappadokia Ariarathes Hanedanina mensuptu. Bundan dolayı Eupator, kendisinin tahta geçmesi ile VI. Ariarathes'in MÖ. yak. 110 yilında katledilmesi arasındaki rastlantıda görüleceği üzere Kapadokia'daki olaylara müdahil olmaya çalıștı. Gerek VII. Ariarathes, gerekse kardeşi VIII. Ariarathes'in ölümlerinden sonra Mithridates, tahta geçme hususunda Ariarathes sülalesinin en büyük erkek üyesiydi, Kapadokia'nın ilhakı da pekâlâ meşrulaşmış olacaktı. Genç Pontos prensi IX. Ariarathes'in tahta çlkması geçici bir çözümdü, fakat hem Roma, hem de Kappadokia soylular kesimi buna razı gelmediler, I. Ariobarzanes Philorhomaios da kral tayin edildi.

Anahtar Kelimeler: Marius • Mithridates Eupator • Ariarathes • Kappadokia • Pontos • Sulla • Ariobarzanes.

There is little information about the meeting between Mithridates Eupator and Caius Marius in 98 B.C. Our sole reference is a concise passage in Plutarch and, indirectly, a quotation in Appian that seems very general and vague ${ }^{1}$. The background of this interview, therefore, remains imprecise in

* Prof. Dr., Universidad de Sevilla, Departamento de Historia Antigua, Facultad de Geografía e Historia, C / María de Padilla s/n 41004-SEVILLA (ESPAÑA).lbpastor@us.es

This paper has been drawn up within the Research Project FFI 2011-25506, "Etnicidad helénica y pervivencia indigena en un territorio de frontera cultural: Anatolia grecorromana”, sponsored by the Spanish Ministerio de Educación.

1 Plut Mar. 31; App. Mith. 56. This trip of Marius is also attested in Cic. Brut. I. 5.3 and Rhet. Her. 55: on this neglected reference, see Fowler 1920, 91 ff. This episode has been specifically studied by Sordi 1973; Ballesteros-Pastor 1999; Molev 2005. On Appian's passage, see Desideri 1973, 12; Famerie 2007, 99. For further studies, see above all Van Ooteghem 1964, 254 ff.; Luce 1970; McGing 1986, 76; Evans 1994, 127; Kallet-Marx 
our sources, and the circumstances surrounding the episode can only be inferred indirectly. As we will see in this paper, Marius goes before the king neither impelled by a mere touristic curiosity, nor seeking to further increase his fame. On the contrary, Marius actually intervenes in defence of the interests of the Republic ${ }^{2}$. The Roman consular speaks with Mithridates at a particularly sensitive moment for international relations in Late-Hellenistic Anatolia. According to our hypothesis, the mediation of Marius probably contributed to modify Eupator's plans in regard to Cappadocia and the Pontic policy towards Rome as well.

As we have shown in a recent article, it is quite likely that queen Laodice, the wife of Mithridates $\mathrm{V}$ of Pontus, belonged to the dynasty of the Cappadocian Ariarathids. This kinship between both royal houses appears suggested by some isolated passages in Appian, as well as in Justin's phrase pointing Ariarathes IX, the son of Mithridates who ruled in Cappadocia, as a descendant of the prestigious Ariarathes V (died ca.129 B.C.) $)^{3}$. Another indication of this relationship would be the possible adoption of the epithet Eusebes by Mithridates Eupator during part of his childhood, prior to taking the surname Dionysus ${ }^{4}$. It is worth remembering that, most likely, Ariarathes VII of Cappadocia was born about 125 B.C., and therefore Eupator would have been a candidate for the succession to that kingdom in case of the death of Ariarathes VI ${ }^{5}$. Accordingly, the adoption of the surname Eusebes, with the highest reputation among the Ariarathids, would have been a key factor for Mithridates in order to manifest his dynastic legitimacy before the Cappadocians ${ }^{6}$. Alongside this, Eupator's reference to Alexander the Great as one of his maternal ancestors -expressed in Justin's harangue-, could be interpreted as an specific allusion to the Seleucid blood of the Pontic king's mother, because the Cappadocian rulers had been married to different Seleucid princesses since the III c. B.C ${ }^{7}$. In short, the kinship between the Ariarathid and Mithridatid houses explains

1995, 244 ff.; Ballesteros-Pastor 1996, 66 ff.; De Callataÿ 1997, 271 f.; Mastrocinque 1999, 25 f.; Arslan 2007, 99 ff. Sherwin-White $(1977,74)$ suggested that Plutarch's notice may have been apocryphal.

2 It has been supposed a period of concordia ordinum in Rome after the violent death of the tribune L. Appuleius Saturninus (100 B.C.), and Marius' Eastern mission has been related to this political background: Bulin 1983, 32; Brennan 1992, 146; Ballesteros-Pastor 1996, 70f.

3 App. Mith. 9-10, cf. 12; Iust. XXXVIII. 2. 5; Ballesteros-Pastor 2014a.

4 Ballesteros-Pastor 2014a. This hypothesis is based in a possible reconstruction of the surname in IDélos 1560, instead of Eutyches (CIG 2277a) or Evergetes (Plassart 1912, 427f.; Robert 1978, 160). The first dated reference to Mithridates as Dionysus comes from the Delian inscription IDélos 1562 (ca.101 B.C.).

5 Ariarathes V died $c a .129$ B.C. in the war of Aristonicus, and the widow queen held the regency until the accession of Ariarathes VI (Iust. XXXVII. 1. 2-5). This king would have married princess Laodice of Pontus ca. 126/125, because their son Ariarathes VII reached Persian manhood (i.e. 24 or 25 years old) $c a .100 / 99$ B.C.: see Ballesteros-Pastor 2013, $87 \mathrm{ff}$. About this marriage, see Iust. XXXVIII. 1-5; Memn. FGrHist 434 F1 22. 2; cf. OGIS 342. Ariarathes VI was murdered ca. 110: see Ballesteros-Pastor 2013, $87 \mathrm{ff}$. About the situation in Cappadocia at that moment, note Justin's phrase (XXXVIII. 2. 3): Nicomedes, rex Bithyniae, vacuam morte regis Cappadociam invadit. In 46 B.C., a noble called Lycomedes alleged to belong to the Cappadocian royal house (Bell. Alex. 66), but we have no concrete information about this kinship. On the age of manhood among the Persians, see Xen. Cyr. I. 2. 13; Str. XV. 3. 18; cf. Hdt. I.209. 2.

6 The main cities in Cappadocia were named Eusebeia on the Argeus and Eusebeia on the Taurus, respectively: see Cohen 1995, 377 ff.; Michels 2009, 314 f. The surname Eusebes was borne by Ariarathes IV, Ariarathes V, Ariarathes IX, Ariobarzanes III and Ariarathes X: see Muccioli 2013, $309 \mathrm{ff}$. There was a Cappadocian princess named Eusebia: Clinton 2005, 202 f., no. 272, I-V; Habicht 2007, 151 f.

Iust. XXXVIII. 7. 1: maternos (i.e. ancestors) a magno Alexandro ac Nicatore Seleuco, conditoribus imperii Macedonici. Ariarathes III of Cappadocia married a daughter of Antiochus II; Ariarathes IV, one of Antiochus 
certain episodes that may have been behind Eupator's eagerness to control the neighbouring kingdom, and justifies the collaboration of some Cappadocian groups with this ruler. This network of relations and conflicting interests makes it easier to understand, among other things, that there was a coincidence between the death of Ariarathes VI and Eupator's coming to the throne ca.110 B.C., that this king imprisoned his mother when he began his effective rule, and that she tried to put an end to her own son's life ${ }^{8}$.

We cannot confirm if the death of Ariarathes VI Epiphanes was due to an attempt by his brother-in-law (and cousin) Eupator to seize power in Cappadocia ${ }^{9}$. In any case, it seems that the young Ariarathes VII, son of the former Cappadocian ruler, was protected by his mother, the Pontic princess Laodice, and hence his adoption of the epithet Philometor ${ }^{10}$. While he and his younger brother lived, the Ariarathid dynasty could be considered safe. As we know, however, Ariarathes VII was murdered by his uncle Eupator towards 99 B.C. This act of violence, witnessed by the armies of Pontus and Cappadocia, took place when war was about to break out between both kingdoms ${ }^{11}$. Ariarathes VII had recently reached manhood, and he was not willing to obey his uncle's orders.

After the death of this Cappadocian ruler, his younger brother (Ariarathes VIII) tried to vindicate his right to the kingdom, although only for a brief time, as this prince was beaten and died shortly after ${ }^{12}$. Therefore, apart from this ephemeral attempt at resistance, the dynasty of the Ariarathids could be regarded as extinct towards 99/98 B.C. Thus, the question arises almost spontaneously as to why did Mithridates not proclaim himself king of Cappadocia, given that he belonged to the line of the Ariarathids? There were, indeed, many reasons to justify such a decision: to Eupator's dynastic rights it should be added that a faction among the Cappadocian nobility, led by Gordius, was favourable to the Pontic king and acted in collusion with him on several occasions ${ }^{13}$. Mithridates had bought some territories in Armenia Minor to a noble who very likely

III; Nysa, the wife of Ariarathes V probably was a Seleucid: see D.S. XXXI.19. 6-7; Porph. FGrHist 260 F32.6; Iust. XXVII. 3. 7; App. Syr. 5. On Nysa, see in particular Iust. XXXVII. 1. 4-5. (who wrongly calls her Laodice); cf. OGIS 352; Reinach 1890, 53, 90; Seibert 114 ff.; De Callataÿ 1997, 188 n. 21; Michels 2009, 32, 312.

8 Eupator ascended the throne when he was 23 years old, at the end of his Persian childhood (Sall. Hist. fr. II. 75M; cf. Iust. XXXVIII. 8. 1), and coinciding with a comet which appeared in this year (Iust. XXXVII. 2. 2): see Ballesteros-Pastor 2013, 82 ff. (with further bibliography). About Laodice's imprisonment, see App. Mith. 112; Sall. Hist. fr. II. 75M; Sen. Contr. VII. 1. 15; Memn. FGrHist 434 F1 XXII. 2. On the attempts to murder the young Eupator, see Iust. XXXVII. 2. 4-8; Ballesteros-Pastor 2013, 128 ff.; Id. 2014b. On the date of the death of Ariarathes VI, and about his Persian childhood, see above n.5.

9 Justin (XXXVIII. 1. 1, 5) attributes this murder to a plan of Mithridates, although it may be doubtful (cf. XXXVIII. 5. 8).

10 Muccioli 2013, $249 \mathrm{f}$.

11 Iust. XXXVIII. 1 9-10; 38. 7. 9; Memn. FGrHist 434 F1 XXII. 1.

12 On Ariarathes VIII see Iust. XXXVIII. 2. 1-2; Ballesteros-Pastor 2013, 189 f. (with bibliography). There are coins from two years of Ariarathes VIII, although we cannot date precisely the exact length of his reign: see De Callataÿ 1997, $194 \mathrm{ff}, 271 \mathrm{f}$. This scholar dates Marius' mission after the defeat of this young king.

13 On Gordius, see Iust. XXXVIII. 1. 6; 3. 2; 5. 9; Plut Sull. V. 3; App. Mith. 65; Pomp. Trog. Prol. 38; Portanova 1988, 268 ff.; Ballesteros-Pastor 2013, $173 \mathrm{ff}$. 
was a Cappadocian as well ${ }^{14}$. Besides, the traditional division between the Cappadocian aristocrats could have been a factor which made feasible the setting of Eupator in the throne at Mazaca ${ }^{15}$. Despite all these advantageous circumstances, however, Mithridates left Cappadocia as a nominally independent kingdom, establishing on the throne his eight-years-old son, who is usually numbered as Ariarathes IX ${ }^{16}$. We believe that the reason for Eupator's reluctance is to be found primarily on the pressure of the Roman Republic, which at this very moment was particularly exerted through Caius Marius.

Marius, as we know, travelled to Pessinus ca. 99/98, alleging the fulfilment of a vow to the Mother of the Gods worshipped in this sanctuary. At the time of the Cimbric wars, a Galatian priest of this temple had appeared in Rome, predicting Marius' future success against the barbarians who threatened Italy ${ }^{17}$. Despite this well known anecdote, Plutarch proposes that Marius was looking for an excuse to leave Rome, in order to avoid the humiliation of witnessing the return of his enemy Metellus Numidicus from exile. Besides, it is affirmed that the general was eager to provoke a new war in the East, and that he had ambitions to gain the splendid treasures of Mithridates ${ }^{18}$.

Despite of Plutarch's suggestions, it is commonly admitted that Marius went to the East not as a private citizen, but he acted as an official legate of the Republic ${ }^{19}$. It is possible, therefore, that Marius was sent to gather firsthand information of the situation in Northern Anatolia. The problems between Pontus and Cappadocia had accelerated in the last months, when Nicomedes of Bithynia had invaded the Ariarathid kingdom ${ }^{20}$. Furthermore, if Mithridates and his nephew Ariarathes IX had their respective armies ready to start a war ca. 99 B.C. (Iust. XXXVIII. 1. 9-10; XXXVIII. 7. 9), there must have been, by both sides, a preceding period with the levying of soldiers and messages requesting aid. To some extent, this situation represented a favourable scenario for Marius, not only justifying a formal interview with Mithridates, but also, in the case of a future war,

14 Strabo XII. 2. 6, mentions a certain Antipater son of Sisis, and we have suggested that the correct name was Sisines, quite common among the Cappadocian nobility: Ballesteros-Pastor 2002-2007, 8; cf. Nep.Dat. 7; App. BC II. 91; Syme 1995, 148 ff.; Debord 1999, 115, 359; Ballesteros-Pastor 2013, 22 n. 78, 29 n. 101, 151.

15 The Cappadocian nobles enjoyed a wide degree of autonomy, and they even had the privilege of signing international treaties together with the King: see above all Str. XII. 2. 9; Plb. XXIV. 14. 9; XXXI. 7. 1; Iust. XXXVII. 1. 5; XXXVIII. 1. 1; 2. 7-8; 5. 9; Cic. Att. VI. 1. 3; Doria 1978, 124; Sullivan 1990, 55; Ballesteros-Pastor 2008, 46; 2013, 162, 245.

16 Iust. XXXVIII. 1. 10. On this king see also Sullivan 1980, 1127; Id. 1990, 52 ff.; De Callataÿ 1997, 180 ff.; 269 ff.; 200 ff.; Ballesteros-Pastor 2013, 184; Simonetta 2007, 31 ff; 79 ff. and passim. Eupator's advantageous position, when Cappadocia was at his mercy, has been highlighted by Glew 1977, 338; McGing 1986, 75.

17 D.S. XXXVI. 13; Plut Mar. XVII. 5-6. Marius probably departed from Rome at the end of 99. On the date of the trip, see Reinach 1890, 99; Badian 1959, 300 ff.; Bulin 1983, 28 n. 9; Luce 1960, 162; Sordi 1973, 370-379; McGing 1986, 76 with n.38; Ballesteros-Pastor 1996, 66 (with further bibliography).

18 Plut Mar. XXXI. 1-2. Metellus Numidicus had departed into exile in order to avoid a confrontation with L. Appuleius Saturninus, an influential tribune of the Marian faction: Van Ooteghem 1964, $241 \mathrm{ff}$.; Evans 1994, 114; Cavaggioni 1998, 117 ff.; Kelly 2006, 84 ff.

19 On Marius as member of a libera legatio, see Passerini 1939; Sordi 1973, 375. For discussion of such hypothesis see Badian 1959, 300; McGing 1986, 76 n. 40. Kallet-Marx 1995, 246, points out that Marius' mission "was no libera legatio but resembled more closely in its formal character the embassy to Attalus in 205 that brought the Magna Mater from Pessinus".

20 On Nicomedes' invasion of Cappadocia, see Iust. XXXVIII. 1. 2-3. This action may be dated ca.100 B.C., although Justin's account offers a dark chronological sequence: see Reinach 1890, 97; Olshausen 1978, 423 f.; McGing 1986, 74 f.; Ballesteros-Pastor 2013, 175 f. 
making the consular appear as the suitable commander of the legions to be sent beyond the Halys. In fact, the Republic dispatched soldiers to Cappadocia a few years later, during Sulla's propraetorship in Cilicia ${ }^{21}$. Anyway, apart from his official status, Marius should have increased his prestige during this trip. We could presume that some cities welcomed the Roman consular, as may have been the case for Mitylene ${ }^{22}$. It is doubtful, however, that the negotiatores at Delos erected an equestrian statue to the Roman consular ${ }^{23}$.

Marius' warning to Mithridates is well known: "O King, either try to be stronger than Rome, or obey her commands in silence"; and it evokes an analogous idea expressed by Alexander to the Romans long ago. Leaving aside the historiographical connotations of these words, Plutarch's account makes sufficiently clear Marius' steadiness: Mithridates should stop challenging Rome while not having forces enough to overcome her ${ }^{24}$. The Pontic annexation of Cappadocia would have represented a substantial alteration of the statu quo in Asia Minor, and the Republic needed to prevent this union at any $\cos ^{25}$. There is no reason to doubt that Marius threatened the Pontic king with a war. In this regard, let us recall that some years earlier Rome had ordered Eupator to evacuate the territories which he had occupied in Paphlagonia ${ }^{26}$. Marius' mission would have gone in the same direction, and the answer of Mithridates had been, once more, obedience.

There were other perspectives in this problematic situation. To Rome's interest in maintaining the independence of Cappadocia, could be joined the possible connection of the Ariarathid house with the Gracchi in former times, and hence the support of members of the Roman popularis faction for this royal family ${ }^{27}$. In addition, the links of Mitrhidates with members of the Senatorial aristocracy may have represented an added issue to Marius' intervention: the dangerous scenario provoked by the Pontic policy had shown the error of those who had regarded Mithridates as a harmless ruler ${ }^{28}$.

21 On Sulla's propraetorship in Cilicia and his intervention in Cappadocia, see Badian 1959; Olshausen 1978, 424; Brennan 1992; Ballesteros-Pastor 1996, 71 ff.; Id. 2008, 55 f.; De Callatä̈ 1997, 273 ff.; Dmitriev 2006, 290 ff.

22 The Mitylenians sided with Marius against Sulla: Plut Luc. IV. 2. Manius Aquillius, who was a member of the Marian faction, took refuge in Mitylene when he fled from Mithridates in 89 B.C.: Vell. II. 18. 3; D.S. XXVII. 37. 1.

23 The traditional view related a statue of a wounded Gaul with this equestrian group: Picard 1932; Marcadé 1969, 119 ff., 362 ff.; Coarelli 1982, 445 f n.52; but this interpretation has been rejected: Queyrel 2009; Ridgway 2001, $297 \mathrm{f}$. The inscription in the base of the monument ( $\left.C I L \mathrm{I}^{2} 845\right)$ was related to Marius, although the name of the honoured personage is lost: see Broughton 1952, 8, and for discussion McGing 1986, 76 n.40; Queyrel 2009.

24 On this phrase see Ballesteros-Pastor 1999, who notes the resemblance with Memn. FGrHist 434 F1 18. 2; Ps. Callisth. 1. 30. 1 p. 27 Kroll; 2. 1.1 p. 64 Kroll. On Memnon's passage, see further Braccesi 2006, 70 ff. On Plutarch's pro-Marian bias regarding this episode, see Ballesteros-Pastor 1999, 507 n. 11 (with further bibliography).

25 See Molev 2005

26 Iust. XXXVII. 4. 5. This episode would have been echoed by the sources which related 40 years of war between Eupator and Rome: App. Mith. 112, 118; Syr. 48; Flor. Epit. I. 40. 2; Oros. Hist. VI. 1. 28; Eutr. VI. 12. 3; Schol. Iuv. X. 273; Aug. Ciu. V. 22. On this episode, see Ballesteros-Pastor 2013, 93 f.; $162 \mathrm{ff.}$

27 On the Ariarathids and the Sempronii Gracchi, see Ballesteros-Pastor 2008, $47 \mathrm{ff}$.

28 The Pontic legates sent to Rome ca. 103 B.C. were insulted by L. Appuleius Saturninus. This tribune was accused before the Senate, and the ambassadors were defended by the fetiales, who belonged to prestigious Roman families: see Broughton 1987, 54 ff.; Canali de Rossi 1997, no. 618; Cavaggioni 1998, 80; BallesterosPastor 2008, 53. It has been supposed that Eupator could have been a client of the Metelli: Rossi 1945, 334; 
It is hard to assume that Marius was looking to directly provoke a war with Mithridates, which was one of the reasons offered by Plutarch (Mar. 31. 2) for the Roman's trip. As McGing rightly pointed out, "Marius was probably investigating the possibility or likelihood of war, rather than actually hoping to cause one"29. In a similar sense, Evans considered that Plutarch's statement was "nothing more than a malicious rumour discovered by the biographer in one of his sources, such as the memoirs of Rutilius Rufus or Sulla" ${ }^{30}$. Indeed, Marius was just a legate, and he would have needed the aid of the proconsuls of Asia and Cilicia to wage a war against Pontus. According to the Lex de Provinciis Praetoriis, these magistrates could not surpass the boundaries of their provinces without the Senate's permission ${ }^{31}$. It has been thought that there were allies of Marius among the Roman governors in the Eastern provinces at this moment, but the possible chronology of these proconsulships does not fit with Marius' mission. In any case, this coincidence is not a determining factor in explaining the reason why the prestigious Roman went to meet Mithridates ${ }^{32}$.

The location of the encounter is a matter of controversy. Plutarch alludes to Cappadocia in a general sense, without specifying whether it was Tauric or Pontic Cappadocia. It is well known that both Mithridates and his subjects were often called "Cappadocians", and thus the meeting would have taken place in Pontus ${ }^{33}$. We consider plausible, however, that the interview was held in the proper Cappadocian kingdom, at the moment when Ariarathes VII had perished ${ }^{34}$. We do not know what could have been the source for Plutarch's passage recounting this episode. If one of them was Posidonius, whom the Chaeronean quotes in this Vita, we would be facing a well-informed author regarding the toponymy of Asia Minor in this period. Let us bring to mind that, in the speech of the pro-Pontic leader Athenion, the Apamean erudite specifies on the one hand that Oppius is the governor of Pamphylia, without mentioning Cilicia, and on the other, that Eupator rules over "Upper Cappadocia", establishing a distinction with the inner land of Tauric Cappado$\mathrm{cia}^{35}$. Thus, if Marius reached up to the court of Sinope, he would have been concretely in

Ballesteros-Pastor 2008, 58. An inoffensive portrait of the king is drawn by Glew 1977; cf. the criticism of this view by McGing 1986, $78 \mathrm{ff}$.

29 McGing 1986, 76.

30 Evans 1994, 127. Interesting is Plutarch's allusion to the aim of Marius to fill his house "with Pontic spoils and royal wealth" (Mar. XXXI. 2): compare with Sall. Hist. fr. IV. 69. 10M. About Rutilius as the possible source of this statement, see further Kallet-Marx 1995, 247. Defending Marius' aim to provoke a war, see Paserini 1939, 64 ff.; Badian 1959, 300; Coarelli 1982. Sordi 1973, 378, proposes instead that Marius wanted to prevent a conflict; cf. also Luce 1970, 194; Molev 2005, and for further references Ballesteros-Pastor 1996, $68 \mathrm{ff}$.

31 On the aims of this law, see Crawford 1996; Giovannini 1998; Ferrary 2000, $167 \mathrm{ff}$.

32 According to the list proposed by Ferrary (2000, 192 f.), neither C. Julius Caesar (brother-in-law to Marius) nor C. Valerius Flaccus held the proconsulship in Asia at the time of the meeting between Marius and Mithridates. It is noteworthy that, in some year between 99 and 97, the governor of Asia was Q. Mucius Scaevola, who took measures against corrupt tax-collectors: see Ferrary, loc. cit. and Brennan 2000, 548. This scholar (2000, 553 ff.; 746) proposed that Caesar held the province of Asia in 99 B.C., although without absolute certainty. See further Ballesteros-Pastor 1996, 68.

33 Syll. ${ }^{3}$ 742; Polyb. V. 43. 2; Posidon. FGrHist 87 F36 apud Athen. V. 212a, 215b, F38 apud Athen. VI. 266e; Cic.Flac. 61; App. Mith. 30; 61; D.S. XXXVII. 28; Plut. Sull. XXII. 4; XXIII. 2; Luc. XIV. 4; Cras. VIII. 4; Luc. Ciu. II. 592; Str. XIV. 1. 38; cf.11.8. 4

34 Ballesteros-Pastor 1996, 69; Id. 2013, 190; cf. De Callatä̈ 1997, $271 \mathrm{f}$.

35 Posidon. FGrHist 87 F36 apud Athen. V. 213a-b; Ballesteros-Pastor 2005, 397. On Posidonius as the posible source for this passage of Plutarch, see Scardigli 1977, $51 \mathrm{ff}$. 
Paphlagonia, because Maritime Cappadocia began just east of the river Halys ${ }^{36}$. In addition to this, it should be taken into account that from Galatia to the valley of the Halys there existed inner routes, and that Marius perhaps was interested in visiting most of the land inhabited by the Asian Gauls ${ }^{37}$. At the moment of the interview we are studying, Cappadocia was engaged in a civil war, or had just ended one. In all likelihood, Pontic forces took part in this conflict ${ }^{38}$ and this situation would justify Eupator's presence in that kingdom.

Plutarch's brief account of the meeting undoubtedly presents a positive face of Marius, who appears as an honourable Roman in front of a barbarian ruler. Noteworthy is the allusion to Marius' freedom of speech (parrhēsía), in contrast to Mithridates' despotism ${ }^{39}$. This point of view sounds quite similar to the description of the mission of P. Claudius Pulcher before Tigranes II, also reported by Plutarch in his Life of Lucullus ${ }^{40}$. Also remarkable however, is the allusion to the kind reception that Eupator offers to Marius (Plut. Mar. 31. 3), because this could be a proof that the ruler was aware of the legate's influence and of the need to keep the goodwill of the Republic.

Marius' mission impelled Mithridates to a cautious policy. As we have seen, the sovereign put one of his sons on the Cappadocian throne, because he actually had dynastic rights over this kingdom. Eupator's son appears as a ward of Gordius, and supported by the faction led by this noble ${ }^{41}$. At the same time, some philoi of Mithridates could have been managing the government of Cappadocia. Justin tells of Pontic or pro-Pontic praefecti who rule the country during the reign of the puppet-king Ariarathes IX. These praefecti may have been satraps directly in the service of Mithridates ${ }^{42}$. Besides, Frontinus informs us of a combat between Sulla and Archelaus in Cappadocia towards 96 B.C. There is nothing strange in assuming that such a strategos could have acted as the commander of the Pontic troops stationed in this territory ${ }^{43}$.

Marius' warning to Mithridates was effective, and the king avoided the annexation of the neighbouring kingdom. Nonetheless, a sector of the Cappadocian nobility remained feeling unsafe. This group called for the overthrowing of Mithridates' son and the establishment of Ariobarzanes; although it was not done without fighting and after the appearance of Sulla, who led the first Roman

36 See for instance Str. XII. 1. 1; XII. 3. 9. For a compilation of ancient sources, see Olshausen-Biller 1984; ArgoudDes Courtils-Rémy 1988

37 Let us remember the inner route of Lucullus from Galatia to Pontus, and that Domitius Calvinus returned to Asia through Galatia in 48 B.C., as Murena had done during the Second Mithridatic War: see Munro 1901, 56, 59. We could wonder why Marius was interested in visiting Gordium and other places on the route of Alexander: on Gordium's connection with Pessinus, see Sordi 1982. Brennan 1992, 145, proposed that the meeting took place in the part of Galatia that was under Pontic control, but it is hard to suppose a trip of the King, and furthermore we cannot be sure that Eupator held a relevant area in Galatia at that moment: cf. Iust. XXXVIII. 5. 6; Ballesteros-Pastor 2013, 242.

38 On this war, see Iust. XXXVIII. 2. 1-2; Sullivan 1990, 53 f.; Ballesteros-Pastor 1996, 64; Id. 2013, 189 ff. Appian's reference to the $173^{\text {th }}$ Olympiad as the starting point of the Mithridatic Wars (Mith.17) has been related to this conflict: Goukowsky 2001, LXVII; Ballesteros-Pastor 2013, 33.

39 Plut Mar. 31 .3. On this pro-Marian bias, see Scardigli 1977, 51 ff.; Ballesteros-Pastor 1999, 507 f. (with further bibliography).

40 See Plut Luc. XXI. 6; Doria 1973/74, 47-48; Tröster 2008, 138.

${ }^{41}$ Iust. XXXVIII.1.10. On Gordius' functions, see Portanova 1998, 270 f.; Ballesteros-Pastor 2013, 186. On this pro-Pontic (or at least anti-Ariobarznid) faction, see Iust. XXXVIII. 5. 9; Ballesteros-Pastor 2013, 245.

42 Iust. XXXVIII. 2. 1; Ballesteros-Pastor 2013, $187 \mathrm{ff}$.

43 Front. Str. I. 5.18 (who describes Archelaus as praefectus); Ballesteros-Pastor 2013, 189, 191. 
troops which reached Cappadocia ${ }^{44}$. Evidently, the Republic did not look favourably upon the farce organized by Mithridates with his son. The dynastic rights of the Pontics were ignored by the Republic, and kingship was settled on Ariobarzanes I, an openly pro-Roman king ${ }^{45}$. Eupator seemed to have learned his lesson, and decided, in effect, not defy Rome until he had enough strength to guarantee a successful result. A decade later, the Social and Civil Wars weakened Roman power: Mithridates took profit from this favourable situation, perhaps keeping in mind the warning that had been expressed by Marius.

44 On Sulla's campaign, see for instance: Badian 1959; Olshausen 1978, 242 f.; McGing 1986, 204 ff.; Brennan 1992; Kallet-Marx 1995, 248 ff.; Ballesteros-Pastor 1996, 71 ff.; Dmitriev 2006, 290 ff.

45 On Ariobarzanes I Philorhomaios, see in general Sullivan 1980, 1127 ff. Id. 1990, 54 ff.; 174 f. 


\section{BIBLIOGRAPHY}

\section{Ancient Sources}

App. Mithr.

(=Appianus, Mithridateios)

Appian's Roman History. With an English translation by H. White I-IV.

App. Syr. Cambridge, Mass.-London 1912-1913 (The Loeb Classical Library).

(=Appianus, Syriake)

Appian's Roman History. With an English translation by H. White I-IV.

Athen.

Cambridge, Mass.-London 1912-1913 (The Loeb Classical Library).

(= Athenaios, Deipnosophisticarum Epitome)

The Deipnosophistis. With an English translation by C. B. Gulick. London-New York 1928. (The Loeb Classical Library).

Athenaei Deipnosophisticarum Epitome. Rec.: S. P. Peppinki I-II. Leiden 1937-1939.

Aug. Ciu. (= Augustinus, De Civitate Dei)

Sancti Aurelii Augustini De Civitate Dei. Ed. B. Dumbart I-II. Leipzig 1877.

Cic. Att.

(= Cicero, Epistulae ad Atticum)

Letters to Atticus. With An English Translation by E. O. Winstedt I-III. London, New York 1960-1962 (The Loeb Classical Library).

Cicero's Letters to Atticus [New Edition and Translation by] D. R. S. Bailey Vol. I (book I-II)-VII (Indices to Volumes I-VI). Cambridge University Press 1965-1970 Cambridge Classical Texts and Commentaries 3-9).

Cic. Brut. (= Cicero, Brutus)

Brutus. With an English translation by G. L. Hendrickson. London, New York 1971 (The Loeb Classical Library).

Cic. Flac. (= Cicero, Oratio pro L. Flacco)

The Speech in Defence of Lucius Flaccus. With an English translation by L. E. Lord. Cambridge, Mass.-London 1964 (The Loeb Classical Library).

D.S. (= Diodorus Siculus, Bibliotheke Historike)

Diodorus of Sicily. With an English translation by R. M. Geer. London, New York 1947 (The Loeb Classical Library).

Eutr. (= Eutropius, Brevarium ab urbe condita)

The Breviarum ab Urbe Condita of Eutropius. Translated with an introducion and commentary by H. W. Bird. Liverpool 1993.

Flor. Epit.

Front. Str. (= Annaeus Florus, L. Annaei Flori Epitoma De Tito Livio Bellorum Omnium Annorum DCC Libri II)

Lucius Annaeus Florus The Two Books of the Epitome, Extracted from Titus Livius, of All the Wars of Seven Hundred Years. With an English translation by E. S. Foster. London, New York 1929 (The Loeb Classical Library).

(= Sextus Iulius Frontinus, Strategematon)

The Strategems and the Aqueducts of Rome. With an English translation by C. E. Bennett. London, New York 1925 (The Loeb Classical Library).

Iust. (= Marcus Iunianus Iustinus, M. Iuliani Iustini Epitoma Historiarum 
Luc. Ciu.

Memn.

Nep. Dat.

Oros. hist.

Polyb.

Plut. Cras.

Plut.

Plut.

Plut.

Pomp. Trog. prol.

Porph.
Philippicarum Pompei Trogi)

M. Ivniani Ivstini. Epitoma Historiarvm Philippicarvm Pompei Trogi. Accedvnt Prologi in Pompeivm Trogvm. Ed. O. Seel. Stutgard 1972.

Justin. Epitome of the Philippic History of Pompeius Trogus. Translated by J. C. Yardley. With Introduction and Explanatory Notes by R. Develin. American Philological Asscociation Classical Resources, Atlanta, GA: Scholars Press 1994.

(= Lucanus, Bellum Ciuile)

Lucan. The Civil War. Books I-X (Pharsalia) With an English Translation by J. D. Duff. London: Harvard University Press 1962 (The Loeb Classical Library)

(= Memnon, Peri Herakleias)

Memnon. With an Latin Translation by C. Müller. FGrHist III 536, Parisiis 1853.

F. Jacoby (éd.), Die Fragmente der griechischen Historiker, Leiden (1950). Vol. III B F 434, 337-368 (text) ; III C, 267-282 (commentaries) ; III N, 71-176 (notes).

(=Cornelius Nepos, Datames)

Lucius Annaeus Florus: Epitome of Roman History. Cornelius Nepos (The Book on the Great Generals of Foreign Nations). With an English Translation by E. S. Forster and J. C. Rolfe, London: Harvard University Press 1960 (The Loeb Classical Library).

(= Orosius, Historiarum adversus paganos libri VII)

Seven Books of History Against the Pagans. Translated with introduction and notes by I. W. Raymond. New York 1936.

(= Polybios, Historiai)

Polybius, The Histories. Vol. I-VI. With an English Translation by W. R. Paton, Harvard University Press 1922-1968 (The Loeb Classical Library). (= Plutarkhos, Bioi Paralleloi Crassus)

Plutarch's Lives. With an English translation by B. Perrin I-XI. London, New York 1959 (The Loeb Classical Library)

Luc. (= Plutarkhos, Bioi Paralleloi Lucullus)

Plutarch's Lives. With an English translation by B. Perrin I-XI. London, New York 1959 (The Loeb Classical Library)

Mar. (= Plutarkhos, Bioi Paralleloi Lucullus)

Plutarch's Lives. With an English translation by B. Perrin I-XI. London, New York 1959 (The Loeb Classical Library).

Sull. (= Plutarkhos, Bioi Paralleloi Lucullus)

Plutarch's Lives. With an English translation by B. Perrin I-XI. London, New York 1959 (The Loeb Classical Library).

(= Pompeius Trogus, Prologues)

Prologues to the Philippic History of Trogus. Translated by J. C. Yardley. With introduction and explanatory notes by R. Develin. Atlanta, GA 1994.

(= Porphyrios)

"Porphyrios von Tyros (260)". Ed. F. Jacoby, Die Fragmente der 
Posidon.

Ps. Callisth.

Rhet.Her.

Sall. Hist.

Schol. Iuv.

Sen .Contr.

Strab.

Vell.

\section{Modern Literature}

AFLN

ANRW

Argoud et al. 1987
Griechischen Historiker Part I-III. Brill Online, 2014.

(= Posidonius of Apamea, The Fragments).

"Felix Jacoby, "Poseidonios von Apameia (87)". Die Fragmente der Griechischen Historiker, Part I-III. General Editor: Felix Jacoby. Brill. Online 2014.

Posidonius. Vol. I-III: Vol. I. The Fragments. Eds. L. Edelstein, I. G. Kidd. Cambridge University Press (1998), Vol. II. Commentary: i. Testimonia and fragments 1-149; ii. Fragments 150-293 (1988), Vol. III. The Translation of the Fragments (1999) (Cambridge Classical Texts and Commentaries).

(= Pseudo-Callisthenes, Bios Aleksandrou tou Makedonos)

Historia Alexandri Magni (Pseudo-Callisthenes). Recensio vetusta edidit Guilelmus Kroll. Weidman in Berlin, 1926.

Pseudo-Callisthenes, The History of Alexander the Great. Translated by Sir Ernest Alfred Wallis Budge. Gorgias Press Edition 2003.

(= Rhetorica ad Herennium)

Ad C. Herennium de Ratione Dicendi (Rhetorica ad Herennium) with an English Translation by H. Caplan. Book I-IV. Harvard University Press 1964.

(= Sallustius, Historiae)

Sallust, [The War with Catiline, the War with Jugurtha, Orations and Letters from Histories, the Pseudo-Sallustian Works], with an English Translation by J. C. Rolfe. London: William Heinemann 1921 (The Loeb Classical Library).

(= Iuvenalis Scholia).

Scholia in Juvenalem uetustiora. Ed. Paul Wessner. Leipzig: Teubner 1931.

Juvenal and Persius. Edited and Translation by S. M. Braund. President and Fellows of Harvard College 2004 (The Loeb Classical Library).

(= Seneca the Elder, Controversiae)

Seneca the Elder, Declamations, I. Controversiae, 1-6, vol. II: Controversiae, Books 7-10. Suosoriae. Fragments. Edited and Translated by M. Winterbottom. Cambridge Massachusetts: Harvard University Press 1974 (The Loeb Classical Library).

(= Strabon, Geographika)

The Geography of Strabo. With an English translation by H. L. Jones IVIII. London, New York 1917-1932 (The Loeb Classical Library).

(=Velleius Paterculus, Historia Romana)

Roman History. With an English translation by F. Shipley. London 1924 (The Loeb Classical Library).

Annali della Facoltà di Lettere e Filosofia. Napoli. Aufstieg und Niedergang der römischen Welt.

G. Argoud, J. des Courtils - B. Rémy, "Les sites côtiers du Pont-Euxin, de Thémiskyra à Trapézous dans l'Antiquité. Textes littéraires grecques et 
Arslan 2007

Badian 1959

Ballesteros-Pastor 1996

Ballesteros-Pastor 1999

Ballesteros-Pastor 2005

Ballesteros-Pastor 2008

Ballesteros-Pastor 2013

Ballesteros-Pastor 2014a

Ballesteros-Pastor 2014b

$\mathrm{BCH}$

Braccesi 2006

Breglia 1973/1974

Breglia 1978

Brennan 1992

Brennan 2000

Broughton 1952

Broughton 1987

Bulin 1983

Callataÿ 1997 latins, d'Hecatée de Milet, VIe siècle av. J.-C. à Ammien Marcellin, IVe siècle ap. J.-C.”. Ed. B. Rémy, Anatolia Antiqua. Eski Anadolu. Recueil de travaux publiés par l'Institut Français d'Études Anatoliennes d'Istanbul. Varia Anatolica 1. Istanbul-Paris (1987) 69-82.

M. Arslan, Mithradates VI Eupator: Roma'nin Büyük Düssmanı. İstanbul 2007.

E. Badian, "Sulla's Cilician Command". Athenaeum 37 (1959) 279-303.

L. Ballesteros-Pastor, Mitrídates Eupátor, rey del Ponto. Granada 1996.

L. Ballesteros-Pastor, "Marius' Words to Mithridates Eupator (Plut. Mar. 31. 3)". Historia 48 (1999) 506-508.

L. Ballesteros Pastor, “Atenión, tirano de Atenas". SHHA 23 (2005) 385400 .

L. Ballesteros-Pastor, "Cappadocia and Pontus, Client Kingdoms of the Roman Republic. From the Peace of Apamea to the Beginning of the Mithridatic Wars (188-89 B.C.)". Ed. A. Coşkun, Freundschaft und Gefoloschaft in den auswärtigen Beziehungen der Römer (2. Jhr. v. Chr. - 1 Jhr.n. Chr.). Frankfurt a. M. (2008) 45-63.

L. Ballesteros-Pastor, Pompeyo Trogo, Justino y Mitrídates. Comentario al Epitome de las Historias Filípicas (37, 1, 6-38, 8, 1). Spudasmata Band 154, Hildesheim 2013.

L. Ballesteros-Pastor, "A Neglected Epithet of Mithridates Eupator (IDélos 1560)". Epigraphica 74 (2014a) (forthcoming).

L. Ballesteros-Pastor, "Eupator's Unmarried Sisters. An Approach to the Dynastic Struggle in Pontus after the Death of Mithridates V Evergetes". Anabasis 4 (2014) 61-72.

Bulletin de Correspondance Hellénique.

L. Braccesi, L'Alessandro occidentale: Il Macedone e Roma. Roma 2006.

L. Breglia Pulci Doria, "Plutarco e Tigrane II ФI $\Lambda \mathrm{E} \Lambda \Lambda \mathrm{HN}$ ". AFLN 16 (1973/1974) 37-67.

L. Breglia Pulci Doria, "Diodoro e Ariarate V. Conflitti dinastici, tradizione e propaganda politica nella Cappadocia del II secolo a.C.”. La Parola del Passato 33 (1978) 104-129.

T. C. Brennan, "Sulla's Career in the Nineties: Some Reconsiderations". Chiron 22 (1992) 105-158.

T. C. Brennan, The Praetorship in the Roman Republic. Oxford 2000.

T. R. S. Broughton, The Magistrates of the Roman Republic. Vol. II, New York 1952

T. R. S. Broughton, "Mistreatment of Foreign Legates and the Fetial Priests: three Roman Cases”. Phoenix 41 (1987) 50-62.

R. K. Bulin, Untersuchungen zur Krieg und Kriegführung Roms im Osten von 100-68 v. Chr., Europäische Hochschulschriften 177. Frankfurt a.M. 1983.

F. de Callataÿ, L'Histoire des Guerres Mithridatiques vue par les monnaies. Publications d'Histoire de L'Art et d'Archéologie de L'Université Catholique de Louvain, Numismatica Lovaniensia 18. Louvain-la-Neuve 
1997.

Cavaggioni 1998

CIG

CISA

CIL

Clinton 2005

Coarelli 1982

Cohen 1995

Crawford et al. 1996

CS

Debord 1999

Desideri 1973

Dmitriev 2006

Doria 1978

Evans 1994

Famerie 2007

Ferrary 2000

FGrHist

Fowler 1920

Giovannini 2008

Glew 1977

Goukowsky 2001

Habicht 2007

IDélos
F. Cavaggioni, Lucio Appuleio Saturnino. Tribunus plebis seditiosus. Venezia 1998.

A. Böckh, Corpus Inscriptionum Graecarum.

Contributi dell'Istituto di Storia Antica dell'Università del Sacro Cuore. Milano.

Corpus Inscriptionum Latinarum.

K. Clinton, Eleusis. The Inscriptions on Stone. Documents of the Sanctuary of the two Goddesses and Public Documents of the Deme. Athens 2005.

F. Coarelli, "Su alcuni proconsoli d'Asia tra la fine del II e gli inizi del I secolo a.C. e sulla politica di Mario in Oriente". Tituli 4 (1982) t.I, 435-451.

G. M. Cohen, The Hellenistic Settlements in Europe, the Islands, and Asia Minor. Berkeley 1995.

M. H. Crawford et al., "Lex de Provinciis Praetoriis", Ed. M. H. Crawford, Roman Statutes. London (1996) vol. I, 231-270.

Critica Storica. Roma.

P. Debord, L'Asie Mineure au IVe siècle av. J.-C. Pouvoirs et jeux politiques. Bordeaux 1999.

P. Desideri, "Posidonio e la Guerra Mitridatica”. Athenaeum 51 (1973) 329, 237-269.

S. Dmitriev, "Cappadocian Dynastic Rearrangements on the Eve of the First Mithridatic War”. Historia 55 (2006) 285-297.

L. B. P. Doria, "Diodoro e Ariarate V. Conflitti dinastici, tradizione e propaganda politica nella Cappadocia del II secolo a.C.”. PP 33 (1978) 104-129.

R. J. Evans, Gaius Marius. A political biography. Pretoria 1994.

E. Famerie, “Les emplois de 'proboulos' chez Appien”. Eds. J. Denooz, V. Dortu - R. Steinmetz, Mosaïque. Hommages à P. Somville. Liège (2007) 95-102.

J.-L. Ferrary, "Les gouverneurs des provinces romaines d'Asie Mineure (Asie et Cilice), depuis l'organisation de la province d'Asie jusqu'à la première guerre de Mithridate (126-88 av. J.-C.)". Chiron 30 (2000) 161193.

F. Jacoby, Die Fragmente der griechischen Historiker.

W. W. Fowler, Roman Essays and Interpretations, Oxford 1920.

A. Giovannini, "Date et objectifs de la Lex de Provinciis Praetoriis (Roman Statutes, no. 12)". Historia 57 (2008) 92-107.

D. G. Glew, "Mithridates Eupator and Rome. A Study of the Background of the First Mithridatic War". Athenaeum 55 (1977) 380-405.

P. Goukowsky, Appien. Histoire Romaine. Livre XII. La Guerre de Mithridate. Paris 2001.

C. Habicht, "Neues zur hellenistischen Geschichte von Kos". Chiron 37 (2007) 123-152.

P. Roussel; M. Launey, Inscriptions de Délos (Paris 1937). 
JHS

JRS

IS

Kallet-Marx 1995

Kelly 2006

Luce 1970

Marcadé 1969

Mastrocinque 1999

McGing 1986

Michels 2009

Molev 2005

Muccioli 2013

Munro 1901

OGIS

Olshausen - Biller 1984

Olshausen 1978

Paserini 1939

Picard 1932

Plassart 1912

Portanova 1988

Queyrel 2009

RE

Reinach 1890

Ridgway 2001

RIL

Robert 1978
The Journal of Hellenic Studies.

The Journal of Roman Studies.

Journal des Savants.

R. Kallet-Marx, Hegemony to Empire. The Development of the Roman Imperium in the East from 148 to 62 B.C. Berkeley 1995.

G. P. Kelly, A History of Exile in the Roman Republic. Cambridge 2006.

T. Luce, "Marius and the Mithridatic Command". Historia 19 (1970) 161-194.

J. Marcadé, Au Musée de Délos. Paris 1969.

A. Mastrocinque, Studi sulle Guerre Mitridatiche. Historia Einzelschriften 124. Stuttgart 1999.

B. C. McGing, The Foreign Policy of Mithridates VI Eupator, King of Pontus. Mnemosyne supl.89, Leiden 1986.

C. Michels, Kulturtransfer und monarchischer «Philhellenismus». Bithynien, Pontus und Kappadokien in hellenistischer Zeit. Göttingen 2009.

E. A. Molev, "The Meeting between Mithridates and Marius and the Development of Pontus' Military Doctrine". Antiquitas Aeterna 1 (2005) 205-210 (Russian with English summary).

F. Muccioli, Gli epiteti ufficiali dei re ellenistici. Historia Einzelschriften 224. Stuttgart 2013.

J. A. R. Munro, "Roads in Pontus, Royal and Roman". JHS 21 (1901) 5266.

W. Dittenberger, Orientis Graeci Inscriptiones Selectae.

E. Olshausen; J. Biller, Historisch-geographische Aspekte der Geschichte des pontischen und armenischen Reiches. Teil 1. Untersuchungen zur historischen Geographie von Pontos unter den Mithridatiden. TAVO B 29/1, Wiesbaden 1984.

E. Olshausen,"Pontos”. RE Suppl. 15 (1978) 396-442.

A. Paserini, "Epigrafia Mariana”. Athenaeum 17 (1939) 54-77.

G.-C. Picard, "Le guerrier blessé de l'agora des italiens à Délos". BCH 56 (1932) 491-530.

A. Plassart, "Fouilles de Délos exécutées aux frais de M. le Duc de Loubat. Inscriptions du Gymnase”. BCH 36 (1912) 387-435.

J. J. Portanova, The Associates of Mithridates VI of Pontus, Columbia University 1988. Thesis (Ph. D.)

F. Queyrel, "Réalisme et mode de représentation dans l'art du portrait hellénistique: le cas de Délos". Ktema 34 (2009) 243-256.

Realencyclopädie der Altertumswissenschaft Pauly-Wissowa.

T. Reinach, Mithridate Eupator, roi de Pont. Paris 1890.

B. S. Ridgway, Hellenistic Sculpture I. The Styles of ca. 331-200 B.C. Madison, Wisc. 2001.

Rendiconti dell'Istituto Lombardo.

L. Robert, "Monnaies et textes grecques II. Deux tétradrachmes de 
Rossi 1945

Scardigli 1977

Seibert 1967

Sherwin-White 1977

SHHA

Simonetta 2007

Sordi 1973

Sordi 1982

Sullivan 1980

Sullivan 1990

Syll.

TAVO

Tröster 2008

Van Ooteghem 1964
Mithridate V Évergète, roi du Pont”. JS (juil./déc. 1978) 151-163.

R. Rossi, Dai Gracchi a Silla. Ed. S. Mazzarino, Storia di Roma, vol. III, Roma 1945.

B. Scardigli, "Ecchi di atteggiamenti pro e contra Mario in Plutarco", CS 14 (1977) 185-253.

J. Seibert, Historische Beiträge zu den dynastischen Verbindungen in hellenistischer Zeit. Historia Einzelschriften 10. Wiesbaden 1967.

A. N. Sherwin-White, "Roman Involvement in Anatolia 167-88 B.C.". JRS (1977) 62-75.

Studia Storica. Historia Antigua.

A. M. Simonetta, "The Coins of the Cappadocian Kings: a revision and catalogue of the Simonetta collection". Parthica 9 (2007) 9-152.

M. Sordi, "La legatio in Cappadocia di C. Mario nel 99-98 a.C.". RIL 107 (1973) 370-379.

M. Sordi, "Il confine dell'Tauro e dell'Halys e il sacrificio en Ilio", Ed. M. Sordi, Politica e religione nel primo scontro tra Roma e l'Oriente. CISA 8. Milano 1982, 136-149.

R. D. Sullivan, "The Dynasty of Cappadocia”. ANRW II, 7.2 (1980) 11251168.

R. D. Sullivan, Near Eastern Royalty and Rome, 100-30 BC. Phoenix Supplement 24. Toronto 1990.

W. Dittenberger, Syllogue Inscriptionum Graecarum. Leipzig 1915-1924.

Tübingen Atlas des Vorderer Orients.

M. Tröster, Themes, Character and Politics in Plutarch's Life of Lucullus. The Construction of a Roman Aristocrat. Historia Einzelschriften 201. Stuttgart 2008.

J. Van Ooteghem, Caius Marius. Namur 1964. 